

\section{Sumário}

O USO DE BOTS SOCIAIS COMO AMEAÇA À DEMOCRACIA .............................................................13

Mateus de Oliveira Fornasier

In Memoriam: The Republican Form and the Separation-of-Powers Among the Four

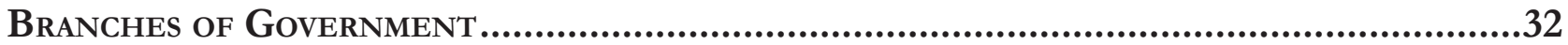

Farris Lee Francis

TODOS E CADA UM DE NÓs: O INTERESSE PÚBLICO COMO CRITÉRIO DE DESENVOLVIMENTO HUMANO

Mártin Haeberlin e Flávio Comim

FACTORES DERIVAdos DE LA POBREZA MULTIDIMENSIONAL QUE AFECTAN LA USABILIDAD DEL e-gobierno en México

Oscar Yahevh Carrera Mora, Luis Fernando Villafuerte e Saulo Sinforoso Martínez

¿Qué ha PASAdo CON Los PRINCIPIOS DE Universalidad, Solidaridad y EFICIENCIA DEL Sistema General de Seguridad Social en Salud de Colombia?

David Mendieta e Carmen Elena

CHANGING THE BENCH FOR A HANDSHAKE: LITIGATION, ADMINISTRATIVE RESOLUTION AND MEDIATION IN FREEDOM OF INFORMATION COMPLAINTS IN CHILE

Pablo Contreras

A evolução identitária da Controladoria-Geral da União: polifonia e decisões em POLÍTICAS DE TRANSPARÊNCIA E ACESSO À INFORMAÇÃO

Érica Bezerra Queiroz Ribeiro e Bruno Amaral Machado

As RAÍZES CRISTÃS DO PRINCÍPIO JURÍDICO DA FRATERNIDADE E AS CRISES MIGRATÓRIAS DO TERCEIRO MILÊNIO.

Maria Celeste Cordeiro Leite dos Santos e Marilene Araujo

JUDICIALIZAÇÃo DESCENTRALIZADA E INDIVIDUALIZADA DA POLÍTICA: MUDANÇAS NAS REGRAS DE tramitação de Medidas Provisórias a partir da Emenda Constitucional 32 155 Leandro Molhano Ribeiro e Mariana Novotny Muniz

O PAPEL DO CNJ DIANTE DO RECONHECIMENTO DO ESTADO DE COISAS INCONSTITUCIONAL DO SISTEMA CARCERÁRIO BRASILEIRO NA PERSPECTIVA DO ATIVISMO DIALÓGICO. 176 Ana Paula Kosak e Estefânia Maria de Queiroz Barboza 
Efeitos do Programa Mais Médicos (PMM) nos resultados da Atenção Básica À SAÚDE.

Alex dos Santos Macedo e Marco Aurélio Marques Ferreira

OrÇamento para os direitos das CRianÇas E adolescentes EM CuRitiba: Plano E EXECUÇÃO

Karoline Strapasson Jambersi e Antonio Gonçalves de Oliveira

A Capacidade do Estado frente a gestão de riscos e desastres após a Política Nacional de Proteção e Defesa Civil (Lei 12.608/2012) .............................................245

Larissa Maria da Silva Ferentz e Carlos Mello Garcias

REFunCIONALIZAÇÃo da PENA DE PRISÃo: ABORDAGEM ACERCA DA ALIENAÇÃo DO TRABALHO

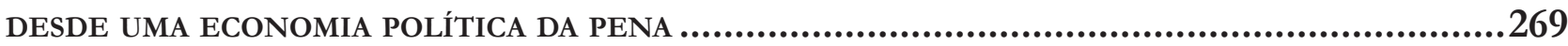
Jackson da Silva Leal

LA CONSTITUCIONALIZACIÓN DEL DERECHO A DEFENSA JURIDICA DE LAS VICTIMAS EN CHILE 286 Marcela Peredo Rojas

COLABORAÇÃo PREMIADA E SELETIVIDADE DO SISTEMA PENAL: PROBLEMATIZAÇõES ACERCA DA UTILIZAÇÃo de aCordos Na Operação LaVa Jato

Maiquel Ângelo Dezordi Wermuth e Maurício Habckost Dalla Zen

Poder, MASCULINIDAde E PARTICIPAÇão EM FaCções CRIMINOSAS A PARTIR DE RELATOS ADOLESCENTES PRIVADOS DE LIBERDADE PELA PRÁTICA DE ATOS INFRACIONAIS

Jailson Alves Nogueira, Ramon Rebouças Nolasco de Oliveira, Lauro Gurgel de Brito e Veruska Sayonara de Góis

MobILIZAÇÃo JURÍDICA E O DIREITO AO ABORTO NO BRASIL: A EVOLUÇão ARGUMENTATIVA NAS RESPECTIVAS AÇÕES DE CONTROLE CONCENTRADO DE CONSTITUCIONALIDADE .355

Fabiano Hartmann Peixoto e Thales Alessandro Dias Pereira 


\title{
Judicialização descentralizada e individualizada da política: mudanças nas regras de tramitação de Medidas Provisórias a partir da Emenda Constitucional 32*
}

\author{
Decentralized and Individualized Polity \\ Judicialization: Changes in Provisional \\ Measures' Procedural Rules since the \\ Constitutional Amendment 32
}

Leandro Molhano Ribeiro**

Mariana Novotny Muniz***

\section{Resumo}

$\mathrm{O}$ artigo tem como objetivo analisar o caso do Mandado de Segurança $n^{\circ}$ 27.931, que judicializou uma das regras constitucionais referentes à tramitação de medidas provisórias, determinando o alcance da expressão "deliberações legislativas" (artigo 62, \$ $6^{\circ}$, Constituição Federal). Por meio de análise qualitativa de documentos do Congresso (Questões de Ordem) e do Supremo Tribunal Federal (Ações Diretas de Inconstitucionalidade e Mandados de Segurança) e, em diálogo com a literatura especializada, mostramos que esse caso exemplifica um tipo de judicialização pouco explorado no Brasil. Primeiro, o objeto de judicialização foi uma regra que diz respeito ao trâmite processual das Medidas Provisórias no Congresso, ou seja, as próprias regras estruturantes do jogo político foram judicializadas. Segundo, o caso mostra como, no contexto da decisão tomada por Temer, a possibilidade de que a questão fosse judicializada sempre esteve presente no cálculo dos atores políticos, fazendo com que o parlamentar atue como uma espécie de juiz constitucional ao antecipar posicionamentos do tribunal a respeito da questão política em disputa. Terceiro, o caso exemplifica uma decisão judicial individualizada e descentralizada da política, em que poucos atores (o Presidente da Câmara, um Deputado Federal e um Minsitro do STF) foram suficientes para promover uma mudança institucional relevante — já que as regras de medias provisórias tem consequências importantes para dos poderes de agenda e de veto do Executivo e do Legislativo.

Palavras-chave: Judicialização da política. Processo decisório. Mudança institucional. Medidas Provisórias. Congresso Nacional. Supremo Tribunal Federal.

* Recebido em $11 / 03 / 2020$

Aprovado em 06/04/2020

** Doutor em Ciência Política pelo IUPERJ/

UCAM. E-mail: leandro.ribeiro@fgv.br.

\section{Abstract}

This article aims to analyze the Security Mandate's n. 27.931 case, in which one of the Provisional Measures' procedural rules was judicialized, having 
the Brazilian Federal Court determined the meaning of the expression "legislative deliberations" (article 62, $\$ 6^{\circ}$, Federal Constitution). Through the qualitative analysis of documents from the National Congress and from the Brazilian Federal Supreme Court and in dialogue with the specialized literature, this article demonstrates that the case exemplifies a judicialization case not very explored by the Brazilian literature. Firstly, the object of the case was a rule concerning the provisional measures' procedure in the National Congress, meaning that the very rules of the political system were judicialized. Secondly, the case shows how the possibility of the issue in question being judicialized was anticipated by the political actors involved, making them act as a type of constitutional judge. Thirdly, the case shows a decentralized and individualized polity judicialization, in which few actors were sufficient to promote institutional change.

Keywords: Polity judicialization. Decision-making process. Institutional change. Provisional measures. Brazilian National Congress. Brazilian Federal Supreme Court.

\section{Introdução}

A Constituição Federal inaugurou o instituto da medida provisória (MP), que se configurou como um instrumento nas mãos do Presidente da República equiparado aos decretos-leis existentes durante o período da ditadura militar: um ato normativo do Chefe do Executivo que tem força de lei, entrando em vigor logo após sua edição, mas cuja aprovação depende do Congresso Nacional. A diferença essencial entre os dois institutos é que, no caso da medida provisória, há necessidade de manifestação do Congresso para sua aprovação, enquanto, no caso dos decretos-lei, o silêncio do Congresso significava sua aprovação tácita. ${ }^{1}$ Embora a Constituição fale que sua adoção se justifique em "casos de relevância e urgência”, a elevada edição de MPs desde 1988 indica que o instituto era um instrumento corriqueiro usado pelo governo para aprovar suas diferentes propostas de políticas públicas. ${ }^{2}$

Em 2001, foi aprovada a $\mathrm{EC} \mathrm{n}^{\circ} 32$ que tinha como um de seus motivos explícitos limitar o uso excessivo de MPs. A EC no 32 delineou limitações importantes para a edição de medidas provisórias (MPs) pelo Presidente da República. ${ }^{3}$ A partir de então, caso uma MP não fosse apreciada no prazo de 60 dias, aconteceria sua "perda de eficácia", que funciona como uma revogação tácita de tal medida. Procurava-se, assim, criar um desincentivo para que o Presidente editasse MPs em excesso. No entanto, ao mesmo tempo, foi introduzido o "regime de urgência", de modo que — decorridos 45 dias da publicação da MP pelo Presidente — ela trancaria a pauta da casa legislativa em que estivesse tramitando, impedindo outras deliberações legislativas na casa. ${ }^{4}$ A edição de MPs, ao contrário do que esperado pelos congressistas, não diminuiu e, desse modo, a pauta das casas passou a ser constantemente trancadas pelos regimes de urgência das MPs. ${ }^{5}$ Ou seja, com a

\footnotetext{
A interpretação da não apreciação das MPs como uma rejeição tácita foi discutida no próprio Congresso Nacional em 1989 e, posteriormente, foi confirmada pelo STF em 1990, na ADI 295. CALIMAN, Auro A. Leis delegadas e medidas provisórias: notas sobre a atividade legislativa do executivo no Brasil. Revista Jurídica "9 de Julho", São Paulo, n. 2, p. 182-203, 2003; BRASIL. Supremo Tribunal Federal. Ação Direta de Inconstitucionalidade 295. Plenário. Relator: Ministro Marco Aurélio. Sessão de 22/06/1990. Diário de Justiça, Brasília, DF, 22 ago. 1997.

2 FIGUEIREDO, Argelina; LIMONGI, Fernando. Executivo e Legislativo na nova ordem constitucional. Rio de Janeiro: Editora FGV, 1999; FIGUEIREDO, Argelina; LIMONGI, Fernando. Instituições políticas e governabilidade: desempenho do governo e apoio legislativo na democracia brasileira. In: MELO, Carlos; SAEZ, Manuel. A democracia brasileira: balanço e perspectivas para o século 21. Belo Horizonte: UFMG, 2007. p. 25-32; ABRANCHES, Sérgio. Presidencialismo de coalizão: raízes e evolução do modelo político brasileiro. São Paulo: Companhia das Letras, 2018.

3 OLIVEIRA, João Paulo de. Medidas Provisórias na Emenda Constitucional 32. Revista Virtual da AGU, Brasília, ano 3, n. 18, 2002; ARGUELHES, Diego Werneck. Old courts, new beginnings: judicial continuity and constitutional transformation in Argentina and Brazil. 2014. Dissertação (Doutorado) - Faculdade de Direito, Universidade Yale, New Haven, 2014.

4 De acordo com $\$ 6^{\circ}$ da Emenda Constitucional 32/2001, "Se a medida provisória não for apreciada em até quarenta e cinco dias contados de sua publicação, entrará em regime de urgência, subsequentemente, em cada uma das Casas do Congresso Nacional, ficando sobrestadas, até que se ultime a votação, todas as demais deliberações legislativas da Casa em que estiver tramitando".

$5{ }^{7}$ Sobre a implementação da EC 32 e suas consequências ver MACHIAVELI, Fernanda. Medidas Provisórias: os efeitos não an-
} 
EC n ${ }^{\circ} 32$, não só o poder do Executivo sofreu limitações, mas também aquele do Congresso, que se deparou com o trancamento recorrente da pauta de ambas as casas legislativas dado o "regime de urgência" (artigo $\left.62, \int 6^{\circ}, \mathrm{CF}\right)$.

Os presidentes da Câmara dos Deputados tentaram, em diversos momentos, reinterpretar a expressão "deliberações legislativas" inscrita pela EC no 32 com o objetivo de delimitar o alcance do sobrestamento. ${ }^{6} \mathrm{~A}$ mais relevante de tais reinterpretações é a do então presidente da Câmara, Michel Temer. No dia 11 de março de 2009, Michel Temer, ao responder à Questão de Ordem 411, afirmou que deveria ser realizada uma interpretação sistêmica do termo, de modo que o trancamento só alcançasse os projetos de lei ordinária, que são aqueles cujos temas uma MP pode versar. Assim, outras atividades legislativas, como deliberações sobre projetos de lei complementar ou de emenda à Constituição poderiam ser livremente votados. Alguns dias depois (18 de março), entretanto, o deputado Ronaldo Caiado, membro da oposição, impetrou um mandado de segurança (MS no 27.931) ${ }^{7}$ no Supremo Tribunal Federal (STF), questionando a constitucionalidade da interpretação de Temer. No dia 27 do mesmo mês, o relator do MS, Celso de Mello, indeferiu o pedido de liminar, autorizando a nova interpretação. Somente 8 anos depois, em 29 de junho de 2017, o Plenário do STF decidiu a questão, afirmando a constitucionalidade do entendimento de Temer com apenas um voto contrário, o do Ministro Marco Aurélio.

Esse caso ilustra três aspectos importantes e que merecem ser mais explorados a respeito da judicialização da política no Brasil:

(1) O objeto de judicialização foi uma regra que diz respeito ao trâmite processual das Medidas Provisórias no Congresso. Vale ressaltar que tal regra interfere diretamente no gerenciamento do presidencialismo de coalizão, por definir os poderes de agenda do Presidente da República em sua relação com o Congresso. Em outras palavras, o alvo da judicialização nesse caso, é um tipo de política pública que estrutura as próprias regras do jogo político, reconhecido na literatura como constituency policy ${ }^{8}$ ou polity ${ }^{9}$ — esse aspecto será tratado na primeira seção.

(2) O caso mostra como, no contexto da decisão tomada por Temer, a possibilidade de que a questão fosse judicializada sempre esteve presente no cálculo dos atores políticos. Como será visto na segunda seção, houve um esforço de Temer em fundamentar sua decisão por meio de um raciocínio jurídico, expondo argumentos constitucionais para, ao mesmo tempo, afastar a interpretação até então vigente a respeito do sobrestamento de pauta e assegurar que a sua posição seria vencedora, caso contestada no STF. Esse aspecto é relevante por exemplificar uma dimensão do conceito de judicialização da política que merece ser analisada de forma detida: a linguagem constitucional usada pelo legislador para fundamentar sua decisão — caso em que o parlamentar atua como uma espécie de juiz constitucional, antecipando estrategicamente possíveis posicionamentos do tribunal a respeito da questão política em disputa. ${ }^{10}$

(3) O resultado final proferido pelo STF é a confirmação de uma decisão liminar dada pelo ministro Celso de Mello oito anos antes. O tempo gasto entre a decisão liminar e o resultado do Plenário exemplifica um tipo de poder individual que um ministro do STF tem para interferir no processo político decisório

tecipados da Emenda Constitucional 32 nas relações entre Executivo e Legislativo. 2009. Dissertação (Mestrado) - Faculdade de Filosofia, Letras e Ciências Humanas, Universidade de São Paulo, São Paulo, 2009.

6 MUNIZ, Mariana Novotny; RIBEIRO, Leandro Molhano. Imaginação, transgressão e formalização: ações do Congresso e do STF na definição de regras de tramitação de Medidas Provisórias. Revista de Estudos Institucionais, no prelo.

7 BRASIL. Supremo Tribunal Federal. Ação Direta de Inconstitucionalidade 295. Plenário. Relator: Ministro Marco Aurélio. Sessão de 22/06/1990. Diário de Justiça, Brasília, DF, 22 ago. 1997.

8 LOWI, Theodore J. Four systems of policy, politics, and choice. Public Administration Review, v. 32, n. 4, p. 298-310, 1972.

9 Este tipo de política seria uma dimensão denominada de "polity" e se refere às regras constitucionais estruturantes do sistema político. Ver tipologia elaborada por ARANTES, Rogério B.; COUTO, Cláudio G. 1988-2019: trinta anos de constitucionalização permanente. In: SOUZA, André P.; M. FILHO, Naercio. A Carta: para entender a Constituição brasileira. São Paulo: Todavia, 2019. p. 13-52.

10 SWEET, Alec Stone. Governing with judges: constitutional politics in Europe. Oxford: Oxford University Press, 2000. 
brasileiro. Os poderes individuais dos ministros do STF não são uma novidade. Diversos estudos têm chamado a atenção para os poderes de veto e agenda que um ministro pode ter no processo decisório interno ao tribunal e o quanto sua ação individual afeta o resultado do processo político mais amplo. ${ }^{11} \mathrm{O}$ caso, por sua vez, mostra a importância de se considerar as regras formais e informais de tomada de decisão interna ao tribunal na explicação de uma judicialização da política que também foi individualizada no acesso ao tribunal. A terceira seção aborda esse aspecto e mostra que o resultado final da judicialização foi o produto de ações individualizadas e descentralizadas, por meio das quais dois parlamentares e um ministro foram suficientes para alterar o status quo. ${ }^{12}$ Vale ressaltar que, nesse caso, um ministro do STF corroborou uma interpretação considerada inovadora do então presidente da Câmara a uma regra que havia sido estabelecida por Emenda Constitucional e que já tinha sido objeto de interpretações anteriores na Câmara. Isso significa que, dadas as regras formais e informais de decisão da Câmara dos Deputados e do STF e as condições de acesso de atores políticos ao Tribunal, ações individuais podem levar a mudanças institucionais relevantes. ${ }^{13}$

O artigo conclui, com uma breve análise de duas consequências, que uma judicialização individualizada e descentralizada pode provocar. Em primeiro lugar, o caso analisado ilustra a possibilidade de implementação de uma inovação institucional conduzida por poucos atores. Em um regime democrático, pressupõe-se que mudanças institucionais sejam o resultado de decisões majoritárias de atores do Executivo e Legislativo. A dificuldade de se promover mudanças no status quo está associada à dificuldade de obtenção de apoios majoritários, que variam em função do grau de divergência de preferências vigentes que podem e devem interferir no processo decisório, em função tanto da fragmentação de preferências existente (número de atores) como da distância ideológica entre eles. ${ }^{14}$ Além disso, os atores políticos não têm o poder ilimitado em democracias constitucionais, justamente porque há garantias inscritas na Constituição que ou não podem ser modificadas (como cláusulas pétreas, por exemplo) ou exigem super-maiorias (maiorias qualificadas) para serem alteradas. ${ }^{15}$ No processo de produção de políticas constitucionais, as cortes constitucionais assumem um papel de veto relevante como protetoras dos direitos constitucionalizados. ${ }^{16}$ Isso faz com que alterações do status quo em regimes democráticos aconteçam a partir do alinhamento de preferências de atores com poder de veto até que se alcance a maioria requerida. O caso analisado no artigo mostra que uma judicialização individualizada e descentralizada ${ }^{17}$ pode promover alterações do status quo sem as interações (ou alinhamentos) necessárias para formação de maiorias. Em segundo lugar, ao dar a palavra final no processo de decisão, o tribunal pode elaborar uma interpretação judicial que amplie seu poder. A expansão do poder

\footnotetext{
11 ARGUELHES, Diego Werneck; RIBEIRO, Leandro Molhano. 'Ministrocracia'? O Supremo Tribunal Individual e o processo democrático brasileiro. Novos Estudos CEBRAP, v. 37, p. 13-32, 2018; ARGUELHES, Diego Werneck; RIBEIRO, Leandro Molhano. Contextos da judicialização da política: novos elementos para um mapa teórico. Revista Direito GV, São Paulo, v. 15, n. 2, p. 1-21, 2019.

12 ARGUELHES, Diego Werneck; RIBEIRO, Leandro Molhano. Contextos da judicialização da política: novos elementos para um mapa teórico. Revista Direito GV, São Paulo, v. 15, n. 2, p. 1-21, 2019.

13 MUNIZ, Mariana Novotny; RIBEIRO, Leandro Molhano. Imaginação, transgressão e formalização: ações do Congresso e do STF na definição de regras de tramitação de Medidas Provisórias. Revista de Estudos Institucionais, no prelo.

14 A dificuldade de alteração do status quo por atores relevantes é discutida por TSEBELIS, George. Veto players: how political institutions work. Princeton: Princeton University Press, 2002.

15 Uma discussão a respeito das dificuldades de alteração de Constituições por causa da configuração das instituições democráticas pode ser encontrada em LIJPHART, Arend. Modelos de democracia. 3. ed. Rio de Janeiro: Civilização Brasileira, 2003.

${ }_{16}$ A participação de cortes constitucionais no processo político decisório é muito discutida na literatura especializada. Nesse artigo fazemos referência sobretudo às discussões de SWEET, Alec Stone. Governing with judges: constitutional politics in Europe. Oxford: Oxford University Press, 2000; BROUARD, Silvain; HÖNNIGE, Christoph. Constitutional courts as veto players: lessons from the United States, France and Germany. European Journal of Political Research, v. 56, p. 529-552, 2017; TAYLOR, Matthew. O Judiciário e as políticas públicas no Brasil. Dados, v. 50, n. 2, p. 229-257, 2007; TAYLOR, Matthew. Judging policy: courts and policy reform in democratic Brazil. Stanford: Stanford University Press, 2008; VIEIRA, Oscar Vilhena. Supremocracia. Revista Direito GV, v. 4, n. 2, p. 441-464, 2008; ARGUELHES, Diego Werneck; RIBEIRO, Leandro Molhano. 'Ministrocracia'? O Supremo Tribunal Individual e o processo democrático brasileiro. Novos Estudos CEBRAP, v. 37, p. 13-32, 2018; TSEBELIS, George. Veto players: how political institutions work. Princeton: Princeton University Press, 2002.

17 ARGUELHES, Diego Werneck; RIBEIRO, Leandro Molhano. Contextos da judicialização da política: novos elementos para um mapa teórico. Revista Direito GV, São Paulo, v. 15, n. 2, p. 1-21, 2019.
} 
de um tribunal constitucional pode ocorrer independentemente do tipo de judicialização, mas o caso ilustra que mesmo uma decisão judicial individual pode pavimentar o caminho para tal expansão.

\section{Judicialização de uma regra do processo decisório}

Normalmente, os objetos da judicialização são os direitos constitucionalizados, sendo a atuação do tribunal mais ou menos abrangente, dependendo da extensão de direitos contemplados na Constituição. ${ }^{18}$ No entanto, Ran Hirschl chama a atenção para uma expansão crescente dos tribunais constitucionais no escopo de suas atuações nas democracias contemporâneas. Segundo o autor, não apenas conflitos a respeito da "justiça procedimental" (ou seja, a contestação da violação dos ritos do devido processo legal) e de direitos civis e sociais são passíveis de contestações judiciais nas democracias atuais, mas também o que ele chama de "megapolítica". Os casos de judicialização da megapolítica incluem a contestação nos tribunais de controvérsias fundamentais da coletividade política, como políticas macroeconômicas, políticas de segurança nacional, regras do processo eleitoral, corroboração de mudanças de regimes políticos e, principalmente, decisões relacionadas a questões de identidade coletiva e/ou construção nacional. ${ }^{19}$

A judicialização da megapolítica tal como definida por Hirschl abarca temas que Couto e Arantes ${ }^{20}$ classificam como políticas públicas (policy) ou seja, resultados conjunturais de decisões do jogo político — e o que os autores denominam de polity, que são parâmetros estruturais da própria arquitetura política (como regras do processo político, por exemplo). ${ }^{21}$ Couto e Arantes chamam a atenção para o fato de que a Constituição brasileira de 1988 tem diversos dispositivos que podem ser classificados como políticas públicas. ${ }^{22}$ Ou seja, no caso brasileiro, muito do que seria resultante de decisões governamentais - e, portanto, resultado de interações políticas conjunturais - foi constitucionalizado. Isso amplia o número de assuntos que podem ser contestados judicialmente no STF, na medida em que não apenas ações governamentais consideradas contrárias a direitos fundamentais podem ser levadas ao tribunal, como também qualquer decisão política cujo conteúdo diga respeito à política pública constitucionalizada.

Entretanto, no caso analisado neste artigo, o objeto de judicialização não foi uma política pública, mas uma regra do próprio processo decisório (polity). Esse tipo de judicialização foi possível por conta do desenho institucional de acesso ao STF que permitiu que um parlamentar contestasse a decisão de Michel Temer por meio de mandando de segurança. O objeto de contestação é importante porque se refere a um tipo de política que define as regras do jogo político e, como tal, distribui poderes de agenda e de veto entre os atores relevantes. Como amplamente discutido na literatura política brasileira, a medida provisória é um instrumento que confere um forte poder de agenda ao Executivo no modelo presidencialista vigente. ${ }^{23}$ Isso porque MPs têm eficácia imediata, o que torna extremamente custoso reverter os efeitos provocados por sua edição e impõe elevado custo para sua rejeição pelo Legislativo. Até a edição da EC no 32, o Executivo podia reeditar indefinidamente MPs, o que lhe conferia elevado poder decisório. A EC n 32 alterou as re-

\footnotetext{
HIRSCHL, Ran. The judicialization of mega-politics and the rise of political courts. Annual Review of Political Science, v. 11, 2008. HIRSCHL, Ran. The judicialization of mega-politics and the rise of political courts. Annual Review of Political Science, v. 11, 2008.

ARANTES, Rogério. Judiciário: entre a justiça e a política. In: AVELAR, Lúcia; CINTRA, Antonio. Sistema político brasileiro: uma introdução. 2. ed. São Paulo: Konrad Adenauer; Unesp, 2007. p. 81-115; ARANTES, Rogério B.; COUTO, Cláudio G. 1988-2019: trinta anos de constitucionalização permanente. In: SOUZA, André P.; M. FILHO, Naercio. A Carta: para entender a Constituição brasileira. São Paulo: Todavia, 2019. p. 13-52.

21 Ou, como dito acima, o que é chamado de "constituency policy" por LOWI, Theodore J. Four systems of policy, politics, and choice. Public Administration Review, v. 32, n. 4, p. 298-310, 1972.

22 ARANTES, Rogério B.; COUTO, Cláudio G. 1988-2019: trinta anos de constitucionalização permanente. In: SOUZA, André P.; M. FILHO, Naercio. A Carta: para entender a Constituição brasileira. São Paulo: Todavia, 2019. p. 13-52.

23 FIGUEIREDO, Argelina; LIMONGI, Fernando. Executivo e Legislativo na nova ordem constitucional. Rio de Janeiro: Editora FGV, 1999; ARANTES, Rogério B.; COUTO, Cláudio G. 1988-2019: trinta anos de constitucionalização permanente. In: SOUZA, André P.; M. FILHO, Naercio. A Carta: para entender a Constituição brasileira. São Paulo: Todavia, 2019. p. 13-52.
} 
gras de tramitação de MPs, redistribuindo os poderes de agenda e de veto entre o Executivo e o Legislativo e entre atores do governo e oposição. A partir de então, entre outras coisas, diversas matérias não poderiam mais ser objeto de MP; as MPs deveriam passar por uma análise prévia de constitucionalidade a ser realizada por uma Comissão Mista do Congresso; as MPs poderiam ser prorrogadas uma única vez; não poderia haver reedição de MP em uma mesma sessão legislativa; caso não apreciadas no prazo de quarenta e cinco dias a partir de sua publicação, a MP entraria em regime de urgência e sobrestaria todas as deliberações da Casa em que estivesse tramitando. ${ }^{24}$

Assim, a decisão de Temer confirmada pelo ministro Celso de Mello recai justamente sob um aspecto importante dos poderes exercidos pelo Executivo e pelo Congresso no trâmite das MPs. Como será visto na seção seguinte, ao reinterpretar as ações no Congresso que deveriam ser classificadas como "deliberações legislativas", Temer na verdade decidiu a respeito do alcance da regra definida na EC n 32 a respeito do sobrestamento de pauta. Sua interpretação restringiu ações legislativas passíveis de trancamento e, consequentemente, aumentou a possibilidade de ação no Congresso. Em síntese, a judicialização da política analisada neste artigo, embora não foque em casos normalmente estudados de contestação de políticas públicas por meio de controle de constitucionalidade concentrado, foi decisiva para redefinir formalmente os poderes do Executivo e do Legislativo em aspectos importantes do processo político decisório que caracteriza do presidencialismo de coalizão brasileiro.

\section{Atuação do legislador como juiz constitucional}

A inclusão do sobrestamento da pauta no trâmite das MPs obrigaria o Congresso Nacional a apreciá-las em um prazo relativamente curto, sob o risco de ter suas atividades legislativas paralisadas. Logo após a implementação da EC n ${ }^{\circ} 32$, houve um aumento na edição de MPs, que passou de uma média de aproximadamente 40 MPs anuais entre 1995 e 2001, para uma média de cerca de 60 MPs entre 2002 e $2007 .{ }^{25}$ Consequentemente, houve também um aumento do trancamento de pauta no Legislativo, que passou de 2,2\% das sessões, em 2001, para 36\%, em 2002. ${ }^{26}$ Essa nova realidade fez com o que o destrancamento de pauta passasse a ser usado como moeda de troca nas negociações entre Executivo e Legislativo, Como afirma Machiaveli:

[...] a negociação entre as lideranças passa necessariamente pelo destrancamento da pauta como condição para votação de projetos do interesse parlamentar". Nesse sentido, as MPs funcionam como instrumento de barganha nas negociações partidárias. O presidente já não precisa do apoio dos líderes para definir a agenda. ${ }^{27}$

Essa situação levou a uma reação por parte dos parlamentares a respeito do significado e alcance do sobrestamento de pauta. Essa reação se deu basicamente por meio do questionamento dos Deputados Federais a respeito do significado do termo "deliberações legislativas" incluído no artigo 62 pela EC no 32. As disputas interpretativas a respeito do que deve ser entendido como deliberações legislativas remonta ao mo-

\footnotetext{
24 A redação do Art. 62 conferida pela Emenda Constitucional 32/2001 alterou profundamente o texto original. Aprovado projeto de lei de conversão alterando o texto original da medida provisória, esta manter-se-á integralmente em vigor até que seja sancionado ou vetado o projeto." (NR)

25 MACHIAVELI, Fernanda. EC 32: a disputa política em torno da regulamentação das medidas provisórias. $32^{\circ}$ Encontro Anual da Associação Nacional de Pós-Graduação e Pesquisa em Ciências Sociais. GT 21 Estudos Legislativos.

26 Almeida observa que a proporção de MPs não orçamentárias aumentou de 42\% do total entre 1995 e 2001 para $49 \%$ entre 2001 e 2012. A autora ressalta, ainda, que entre 1995 e 2001 apenas 21,7\% das MPs foram aprovadas com alteração, enquanto 58\% o foram entre 2001 e 2012, dados que podem indicar que antes da Emenda Constitucional 32/2001 o governo tinha maior controle sobre o conteúdo final das MPs. Ver ALMEIDA, Acir. Informação, delegação e processo legislativo: a política das Medidas Provisórias. Texto para discussão - Instituto de Pesquisa Econômica Aplicada. 2014.

27 MACHIAVELI, Fernanda. EC 32: a disputa política em torno da regulamentação das medidas provisórias. $32^{\circ}$ Encontro Anual da Associação Nacional de Pós-Graduação e Pesquisa em Ciências Sociais. GT 21 Estudos Legislativos.
} 
mento em que a EC no 32 foi instituída e já evidencia o uso de da linguagem constitucional para fundamentá-las. Em 2002, na Questão de Ordem 688, foi questionado se as pautas das Comissões também estariam submetidas ao sobrestamento em caso de não apreciação de MP no prazo de 45 dias. Em resposta, o então presidente da Câmara dos Deputados, Aécio Neves, definiu que apenas o Plenário da Câmara, órgão responsável pela apreciação das MPs estaria sujeito ao trancamento. A fundamentação dada por Aécio Neves se baseou na defesa do que ele chamou de "interpretação teleológica e sistêmica" do texto constitucional:

mas já é consensual na doutrina jurídica que a missão do intérprete das espécies normativas não se exaure em apreciar apenas a literalidade do texto. Pelo contrário, a interpretação de uma norma jurídica, e notadamente a exegese de dispositivos constitucionais, requer a observância de outros aspectos que não somente o sentido literal, gramatical de determinado enunciado. Para desvendar o verdadeiro sentido da norma, é necessária a utilização de outros elementos interpretativos, entre os quais elementos de caráter teleológico e sistemático. Falo, obviamente, do sentido da intenção que orientou a decisão desta Casa. Cumpre, então, indagar a verdadeira finalidade do trancamento da pauta [...]

Ao sustar todas as deliberações da Casa Legislativa, o texto constitucional busca, na verdade, que a votação da medida provisória seja efetuada imediatamente pelo órgão responsável pela sua apreciação, no caso, o Plenário da Câmara dos Deputados, sem que seja preterida por qualquer outra deliberação deste mesmo Plenário. ${ }^{28}$

Esse tipo de fundamentação foi reafirmado na resposta à Questão de Ordem 536, em 2005. O objeto específico da pergunta formulada era se a votação do processo de cassação do mandato do Deputado André Luiz por meio de uma resolução e a escolha de dois representantes do Legislativo para o TCU por decretos legislativos estariam sobrestados, já que uma MP estaria trancando a pauta do Plenário. O argumento levantado pelo Deputado José Carlos Aleluia era de que resoluções e decretos legislativos, como a perda de mandato (resolução) e a indicação para o TCU (decreto legislativo), não seriam propriamente uma "função legislativa", definida como "aquela destinada a produzir normas gerais e abstratas, cujo fundamento repousa diretamente na Constituição”. Segundo o Deputado,

a regra do $\$ 60$ do art. 62 dev[eri]a ser aplicada apenas aos atos de deliberação em procedimentos destinados ao exercício da função legislativa e não a toda e qualquer deliberação adotada pelas Casas do Congresso Nacional, pode ser entendido inclusive como uma redução teleológica, expediente largamente acolhido na jurisprudência pátria. ${ }^{29}$

A interpretação de Aleluia foi deferida pelo Presidente da Câmara dos Deputados na época, Severino Cavalcanti, mas foi contestada pelo deputado André Luiz, por meio de um mandado de segurança impetrado no STF. O ministro Marco Aurélio, em decisão liminar, indeferiu o pedido de André Luiz e confirmou o entendimento da Mesa da Câmara. Observa-se, que, ao ser deferida pelo então Presidente da Câmara dos Deputados Severino Cavalcanti e confirmada pelo STF, a novo entendimento acerca da extensão da expressão "deliberações legislativas" acarretaria um alcance mais restrito do que a interpretação dada anteriormente por Aécio Neves, uma vez que, nesse caso, o termo passou a não contemplar as deliberações da Câmara não destinadas à produção legislativa.

Houve, em seguida, a QO 539, em que se pedia o esclarecimento da decisão tomada na QO 536. Mais uma vez, a Câmara afirmou que

o entendimento de que somente as deliberações legislativas, isto é, as deliberações de que resultam normas gerais, abstratas, impessoais, coercitivas e inovadoras do ordenamento jurídico, apenas essas são alcançadas pelo sobrestamento decorrente da não-apreciação das Medidas Provisórias pelo Congresso Nacional no prazo de quarenta e cinco dias. ${ }^{30}$

28 BRASIL. Questão de Ordem 688/2002. Disponível em: https://www2.camara.leg.br/buscaQordem/?wicket:interface=:3::::. Acesso em: 02 mar. 2020.

29 BRASIL. Questão de Ordem 536/2005. Disponível em: https://www2.camara.leg.br/buscaQordem/?wicket:interface=:6::.:. Acesso em: 02 mar. 2020.

30 BRASIL. Questão de Ordem 539/2005. Disponível em: https://www2.camara.leg.br/buscaQordem/?wicket:interface=:8::.:. Acesso em: 02 mar. 2020. Esse entendimento foi reafirmado em outras Questões de Ordem (541 em 2005, 680 e 681 em 2006, 53,56 em 2007). 
Mas a grande inovação institucional no que se refere ao sobrestamento foi produzida pela interpretação do então Presidente da Câmara, Michel Temer, à QO 411 em 2009. O Deputado Regis de Oliveira questionou se todos os itens do artigo 59, inclusive as resoluções, realmente estariam sujeitos ao trancamento de pauta. Em sua formulação, Oliveira argumentou que todos os atos normativos previstos no artigo 59 podem ser compreendidos como "deliberações legislativas", excetuando-se as resoluções e, por isso, "quando da medida provisória trancar a pauta de deliberações da Câmara dos Deputados, não há tal providência em relação às resoluções, que prosseguem sua tramitação normal, inclusive inclusão na ordem do dia do Plenário, sem qualquer restrição." 31

Ao responder essa Questão de Ordem, Michel Temer afirmou que "além das resoluções, que podem ser votadas apesar do trancamento da pauta por uma medida provisória, também assim pode ocorrer com as emendas à Constituição, com a lei complementar, com os decretos legislativos e, naturalmente, com as resoluções." Disse, ainda, que responderia à questão para que os argumentos apresentados que fundamentam essa decisão constassem das notas taquigráficas para "objeto de contestação, contestação da mais variada natureza, mesmo de ordem judicial." 32

Ao justificar a adoção da nova interpretação, Temer apresentou um argumento de teor político e outro jurídico. O aspecto político ressaltado por Temer tem a ver com a constante paralisação dos trabalhos da Câmara por causa do sobrestamento de pauta provocado pela edição excessiva de MPs. Segundo ele,

se não encontrarmos uma solução no caso interpretativo do texto constitucional que nos permita o destrancamento da pauta, nós vamos passar, Deputadas e Deputados, praticamente esse ano sem conseguir levar adiante as propostas que tramitam por esta Casa que não sejam as medidas provisórias. Aqui, estou me cingindo a colocações de natureza política. Eu quero, portanto, dar uma resposta à sociedade brasileira, dizendo que nós encontramos aqui uma solução que vai nos permitir legislar. ${ }^{33}$

Sua fundamentação jurídica, por sua vez, apoiou-se na divisão das funções primárias de cada Poder, Executivo, Legislativo e Judiciário. Segundo Temer, as interpretações anteriores teriam produzido um sistema de sobreposição do Executivo sobre o Legislativo por algumas razões, sendo elas: (i) o excesso de MPs editadas pelo Executivo; e (ii) a obstrução da pauta e, portanto, a inviabilidade do poder de agenda e funcionamento do Legislativo. Como atividade primária do Poder Legislativo, a atividade legislativa deveria ser exercida primordialmente por tal Poder, cabendo exceções, como é o caso da edição de MPs pelo Chefe do Poder Executivo. Acrescentou, ademais, que "toda vez que há uma exceção esta interpretação não pode ser ampliativa. Ao contrário. A interpretação é restritiva. Toda e qualquer exceção retirante de uma parcela de poder de um dos órgãos de Governo, de um dos órgãos de poder, para outro órgão de Governo só pode ser interpretada restritivamente."

A questão, então, seria entender, a partir dessa premissa restritiva, como interpretar o termo "deliberação legislativa" dado pela nova redação do artigo 62. Ao responder essa indagação, Temer se apoiou em outra premissa, a de que a interpretação do texto constitucional deve ser uma interpretação sistêmica. Em outras palavras, que o dispositivo não poderia ser interpretado de forma literal, mas sim de acordo com o ordenamento jurídico (sistema) como um todo:

Quer dizer, eu só consigo desvendar os segredos de um dispositivo constitucional se eu encaixá-lo no sistema. É o sistema que me permite a interpretação correta do texto. A interpretação literal - para usar um vocábulo mais forte - é a mais pedestre das interpretações. ${ }^{34}$

\footnotetext{
31 BRASIL. Questão de Ordem 411/2009. Disponível em: https://www2.camara.leg.br/buscaQordem/?wicket:interface=:10::.:. Acesso em: 02 mar. 2020.

32 BRASIL. Questão de Ordem 411/2009. Disponível em: https://www2.camara.leg.br/buscaQordem/?wicket:interface=:10::::. Acesso em: 02 mar. 2020.

33 BRASIL. Questão de Ordem 411/2009. Disponível em: https://www2.camara.leg.br/buscaQordem/?wicket:interface=:10::.:. Acesso em: 02 mar. 2020.

34 BRASIL. Questão de Ordem 411/2009. Disponível em: https://www2.camara.leg.br/buscaQordem/?wicket:interface=:10:::.: Acesso em: 02 mar. 2020.
} 
Assim, argumenta que "todas as deliberações legislativas" devem ser interpretadas a partir do que pode versar uma MP e conclui que:

então, em face dessas circunstâncias, a interpretação que se dá a essa expressão "todas as deliberações legislativas" são todas as deliberações legislativas ordinárias. Apenas as leis ordinárias é que não podem trancar a pauta. E ademais disso, mesmo no tocante às leis ordinárias, algumas delas, estão excepcionadas. $\mathrm{O}$ art. 62, no inciso I, ao tratar das leis ordinárias que não podem ser objeto de medida provisória estabelece as leis ordinárias sobre nacionalidade, cidadania, e outros tantos temas que estão elencados no art. 62, inciso I. Então, nestas matérias também, digo eu, não há trancamento da pauta. (as pautas serão trancadas nas sessões ordinárias, nada impedindo, nada impedindo, que em sessões extraordinárias votemos emendas à Constituição, lei complementar, decreto legislativo e resolução. $)^{35}$

O uso de argumentos jurídicos por Temer (e pelos Presidentes anteriores da Câmara) demonstra um fenômeno, descrito por Stone Sweet, como "tomada de decisão judicializada" pelo Legislativo. ${ }^{36}$ Em outras palavras, um legislador que age como juiz constitucional, utilizando argumentos jurídicos para embasar e demonstrar a motivação de suas decisões. Tal fenômeno decorreria de uma linha cada vez mais turva de diferenciação entre a atividade legislativa e jurisdicional. Stone Sweet afirma que as interações intensas e constantes entre os legisladores e os juízes constitucionais teriam feito com que a atividade de legislar e o direito constitucional se tornassem altamente entrelaçados e interdependentes. ${ }^{37}$

Desse modo, políticos eleitos, que podem (e na verdade, devem) tomar decisões com base no seu interesse partidário ou ideológico sem grandes explicações, ${ }^{38}$ começam a se comportar como juízes constitucionais. Como apontado, esse comportamento é evidenciado pelo uso de razões jurídicas para embasar suas decisões, comportamento inerente à função jurisdicional, que demanda a devida fundamentação. De forma mais específica, há um evidente esforço — por parte de Temer — de demonstrar que a interpretação em questão está em harmonia com a ordem constitucional vigente por meio do que ele chama de "interpretação sistêmica" e que a interpretação anterior, por outro lado, violaria o Estado Democrático de Direito instituído em 1988.

A decisão de Temer e a forma como ela foi tomada no Congresso reflete três dimensões enumeradas por Stone Sweet como definidoras de uma atuação de tipo "juiz constitucional”: ${ }^{39}$ (1) sua decisão produziu um contexto normativo em que deliberações constitucionais seriam tomadas; (2) sua decisão objetivou definir as regras do processo decisório no legislativo daquele momento em diante, conferindo às regras uma interpretação do que seria normativamente certo; (3) fundamentou sua decisão com um discurso constitucional — ou interpretação constitucional - para legitimar sua escolha. Ao fazer isso, apresentou os argumentos por meio de um raciocínio constitucional que, por um lado, antecipava possíveis contestações judiciais dos opositores à sua medida, e, por outro, fundamentava sua decisão como juridicamente correta, porque em sintonia como texto constitucional. Na formulação de Stone Sweet, Temer legislou como um julgador constitucional..$^{40}$ Ao fazer isso, como será visto na terceira seção, teve de se contrapor uma visão distinta da interpretação constitucional até então vigente a respeito do sobrestamento de pauta.

\footnotetext{
35 BRASIL. Questão de Ordem 411/2009. Disponível em: https://www2.camara.leg.br/buscaQordem/?wicket:interface=:10:::.: Acesso em: 02 mar. 2020.

36 SWEET, Alec Stone. Governing with judges: constitutional politics in Europe. Oxford: Oxford University Press, 2000.

37 SWEET, Alec Stone. Governing with judges: constitutional politics in Europe. Oxford: Oxford University Press, 2000.

38 Como legisladores são eleitos, sua função é justamente de tomar decisões com base em interesses partidários e dos seus eleitores.

Ver SWEET, Alec Stone. Governing with judges: constitutional politics in Europe. Oxford: Oxford University Press, 2000.

39 SWEET, Alec Stone. Governing with judges: constitutional politics in Europe. Oxford: Oxford University Press, 2000.

40 SWEET, Alec Stone. Governing with judges: constitutional politics in Europe. Oxford: Oxford University Press, 2000.
} 


\section{Antecipação estratégica}

A participação do Judiciário no processo político - e especialmente na elaboração da política constitucional - é evidenciada não apenas pelas decisões tomadas pelos tribunais no exercício do controle de constitucionalidade, como também na incorporação das preferências dos tribunais e ministros nos cálculos dos atores políticos. Segundo Stone Sweet, nas interações entre legisladores e juízes constitucionais, as cortes constitucionais podem exercer um efeito imediato/direto ou indireto/pedagógico sobre o Poder Legislativo. ${ }^{41} \mathrm{O}$ efeito imediato é o resultado das deliberações judiciais a respeito da constitucionalidade das leis. Essas deliberações, com o passar do tempo, provocam o que se pode chamar de efeitos indiretos. Ao expressar preferências do tribunal (ou ministros) a respeito de determinados assuntos, o posicionamento do tribunal (ou ministros) que passa a ser antecipado nos cálculos estratégicos dos legisladores. Ou seja, a possibilidade de contestação judicial das políticas elaboradas na arena legislativa (seja pelo Poder Legislativo, seja pelo Executivo) faz com que os atores políticos considerem de antemão os possíveis posicionamentos dos tribunais. ${ }^{42}$ A possibilidade da participação do judiciário no processo decisório, por sua, leva os atores políticos, em suas interações e deliberações, a suar raciocínios e linguagens judiciais, numa tentativa de fazer valer suas preferências em casos de contestação judicial.

A preocupação com o posicionamento do STF pode ser identificada inicialmente em reunião realizada por Temer na véspera de sua decisão com o ministro das Relações Institucionais, José Múcio, o ministro da Defesa, Nelson Jobim, e o advogado geral da União, José Antonio Toffoli. Segundo a coluna painel editada na época pela jornalista Renata Lo Prete, Jobim teria dito que "o Supremo compra essa tese". "Segundo noticiado pelo jornalista Juliano Basile no Valor Econômico, a tese de Temer teria sido bem recebida pelos ministros do STF. Posteriormente, Michel Temer anunciou previamente sua decisão aos líderes dos partidos na Câmara e soube, na reunião com os líderes, que ela seria questionada no Supremo. Temer chegou a noticiar isso ao dizer que "alguns Líderes se opuseram e até farão uma coisa, pelo menos anunciaram, extremamente útil, que é levar esta matéria ao Supremo Tribunal Federal para que o Supremo decida"44. O presidente da Câmara foi além e acrescentou estar proferindo sua decisão de maneira didática para que "quem quiser interpor medida judicial contra esta minha decisão, a decisão da Presidência, retirará as notas taquigráficas e terá o elemento necessário para levar ao Supremo Tribunal Federal". [...] "O que acho utilíssimo, porque a palavra final do Supremo...” (Temer não completa a frase). ${ }^{45}$

Temer tinha consciência da mudança que sua interpretação acarretaria. Não por acaso, apresentou previamente sua posição a atores políticos experientes e sondou um possível um posicionamento do STF em relação à mudança que pretendia implementar. A fala abaixo mostra que o deputado tinha a judicialização do tema em seu horizonte:

ademais disso, a prudência recomenda que eu aguarde uma decisão do Supremo Tribunal Federal para convocar as sessões extraordinárias. Se houver uma liminar paralisando este meu ato, muito bem, eu não tenho o que fazer. Se não houver uma liminar não paralisando o ato, eu volto a reunir os Srs. Líderes para discutir esta matéria.

\footnotetext{
41 SWEET, Alec Stone. Governing with judges: constitutional politics in Europe. Oxford: Oxford University Press, 2000.

42 Essa é uma dimensão importante porque indica o quanto a judicialização do processo político está internalizada pelos atores políticos. É possível imaginar cenários nos quais decisões passadas tenham efeitos dissuasivos no processo político do presente e nem por isso a política deixou de ser judicializada. Ao contrário, nesses casos, a ausência de ações nos tribunais constitucionais seria um indicador de judicialização da política justamente porque as preferências dos tribunais foram antecipadas.

43 PAINEL da Folha: Temer consultou Sarney e ministros sobre brecha em MPs. Folha Online, 2009. Disponível em: https://m. folha.uol.com.br/poder/2009/03/536563-painel-da-folha-temer-consultou-sarney-e-ministros-sobre-brecha-em-mps.shtml. Acesso em: 03 mar. 2020.

44 BRASIL. Questão de Ordem 411/2009. Disponível em: https://www2.camara.leg.br/buscaQordem/?wicket:interface=:10:.::. Acesso em: 02 mar. 2020.

45 BRASIL. Questão de Ordem 411/2009. Disponível em: https://www2.camara.leg.br/buscaQordem/?wicket:interface=:10::::. Acesso em: 02 mar. 2020.
} 
Assim que Michel Temer profere seu discurso anunciando a nova interpretação, Ronaldo Caiado e Miro Teixeira pedem a palavra. Caiado diz que recorreria à decisão no STF. Miro Teixeira faz um pedido para que Caiado, ao judicializar a Questão de Ordem 411, não pedisse liminar e que o ato de Temer fosse considerado um ato da mesa para ampliar as possibilidades de judicialização da nova interpretação

Se eu tivesse de me opor judicialmente não pediria uma liminar, não tentaria precipitar uma discussão, até porque V.Exa. (Temer) disse que nada fará antes de uma decisão do Supremo Tribunal Federal. Então, que não se peça a liminar, essas pressas aí às vezes prejudicam o debate [...]

E é sobre resposta à questão de ordem que se pretende que se vá ao Supremo? Eu imagino até que nesse, em sede de resposta à questão de ordem, o Supremo poderá dizer que ainda é matéria interna corporis.

Quero sugerir a V.Exa., com a disposição que revela de colocar o assunto em debate, antes mesmo de aplicar aqui a regra, que o faça como ato da Mesa, para permitir que outros instrumentos sejam usados, junto ao Supremo Tribunal Federal, alegando a transgressão a texto constitucional ${ }^{46}$.

Caiado reafirma que judicializará a questão e que recorreria também à Comissão de Constituição e Justiça. Miro Teixeira, antecipando a possibilidade de a decisão final ser dada individualmente, afirma:

se uma norma constitucional é revogada monocraticamente, qual é a garantia do cidadão comum e do Estado Democrático de Direito, tão decantado aqui? A interpretação do Presidente? Dos próximos? Que garantia legal nós temos? ${ }^{47}$

A decisão de Michel Temer se deu sob impacto indireto do STF. O caso ilustra a incorporação por Temer dos possíveis posicionamentos do Tribunal em relação ao sobrestamento de pauta, no cálculo estratégico de suas interações com os demais parlamentares. Parece que a antecipação do possível posicionamento do STF foi importante não apenas para o conteúdo da decisão que seria proferida por Michel Temer, como também pela forma como ele conduziu a apresentação de sua decisão na Câmara. A identificação de convergência por Temer entre sua posição e a do STF — pelo menos da maioria dos ministros do tribunal — levou-o a expor a justificativa da decisão de modo a "facilitar" a aceitação de sua interpretação no tribunal. Por calcular que o STF concordaria com sua decisão, Temer identificou um forte aliado para consolidar sua interpretação a respeito da tramitação de MPs — afinal a decisão do STF seria a palavra final sobre o assunto. Esse resultado não passou despercebido por alguns atores que chegaram a propor formas diferentes de encaminhamento da decisão para de alguma forma não "fechar" a questão pelo STF.

\section{Judicialização individualizada e descentralizada da política}

Além do que foi discutido até o momento, a preocupação do deputado Miro Teixeira exposta acima chama a atenção para aspectos da individualização e descentralização da judicialização da política que merece ser melhor estudado. ${ }^{48} \mathrm{~A}$ judicialização da política normalmente é discutida como um fenômeno bidimensional. Por um lado, expressa algum tipo de tomada de decisão normativa que transfere poderes legislativos para os tribunais - particularmente para os tribunais/cortes constitucionais. ${ }^{49}$ Por outro, como visto anteriormente, refere-se à adoção de linguagens e métodos de decisão judicial por parte de atores políticos do

\footnotetext{
46 BRASIL. Questão de Ordem 411/2009. Disponível em: https://www2.camara.leg.br/buscaQordem/?wicket:interface=:10::.:. Acesso em: 02 mar. 2020.

47 BRASIL. Questão de Ordem 411/2009. Disponível em: https://www2.camara.leg.br/buscaQordem/?wicket:interface=:10::::. Acesso em: 02 mar. 2020.

48 Essa seção se baseia em grande parte no mapeamento teórico das possibilidades de judicialização da política elaborado por ARGUELHES, Diego Werneck; RIBEIRO, Leandro Molhano. Contextos da judicialização da política: novos elementos para um mapa teórico. Revista Direito GV, São Paulo, v. 15, n. 2, p. 1-21, 2019.

49 Neste trabalho consideramos apenas a atuação de tribunais constitucionais. Assim, usaremos os termos corte(s) ou tribunal(is) para nos referir a tribunais constitucionais.
} 
legislativo e do executivo. ${ }^{50}$ É por meio do primeiro sentido indicado acima que normalmente os tribunais constitucionais são incorporados na literatura especializada como atores relevantes no processo político decisório. ${ }^{51}$ Segundo a formulação que pode ser considerada consensual na literatura, a política se judicializa a partir do momento em que os tribunais agem, por meio do exercício do controle de constitucionalidade, para julgar propostas governamentais - legislação, decisões administrativas - e conflitos entre os atores políticos do legislativo e executivo decorrentes do processo de elaboração de políticas públicas. ${ }^{52}$

O controle de constitucionalidade autoriza os tribunais a julgar se as políticas propostas pelos atores políticos estão ou não de acordo com a Constituição. Por isso, a ação dos tribunais pode anular propostas e ações políticas, mesmo que elas contem com o apoio de uma maioria no legislativo/executivo — havendo, assim, a manutenção do status quo. Nesses casos, os tribunais agem como uma espécie de legislador negativo. Há estudos, no entanto, que apontam para uma possível atividade legislativa por parte dos tribunais, na medida em que estes podem interpretar o conteúdo normativo das propostas elaboradas pelos poderes legislativo ou executivo e implementar alguma medida ou alteração não prevista pelos atores políticos. Nesses casos, os tribunais estariam exercendo uma espécie de ativismo judicial, ao extrapolar as atribuições de um mero árbitro dos conflitos entre atores políticos. ${ }^{53}$ Como afirma Stone Sweet, a política constitucional tem um duplo efeito legislativo como legislação negativa pelo lado da demanda, em que atores políticos recorrem aos tribunais para impedir a alteração do status quo e um possível ativismo pelo lado da oferta, em que juízes podem fazer valer suas preferências políticas ao exercer o controle de constitucionalidade. ${ }^{54}$

A forma e o grau da interferência dos tribunais no processo de implementação de políticas se relacionam, por sua vez, com os seguintes fatores: a extensão de temas passíveis de serem contestados nos tribunais; a configuração do desenho institucional do controle de constitucionalidade vigente e das formas pelas quais o tribunal pode atuar e ser acessado; e, também, com características do processo decisório interno do tribunal. ${ }^{55}$ No que se refere ao primeiro caso, é consensual na literatura que a constitucionalização de direitos civis, políticos e sociais nas democracias constitucionais atuais permite uma ampla atuação dos tribunais. No caso brasileiro, por exemplo, Vilhena chama a atenção para o fato de que o "compromisso maximizador" de regulamentar de forma pormenorizada temas de relações sociais, econômicas e públicas na Constituição potencializou o litígio constitucional de tal forma que Supremo Tribunal Federal se tornou um dos principais atores do processo político — praticamente qualquer alteração do status quo pode ser objeto de contestação

50 Esse aspecto bidimensional foi apresentado por Tate e Valinder no artigo "Judicialization and the Future of Politics and Policy", publicado em 1995 (VALLINDER, T.; TATE, C. Neal. Judicialization and the future of politics and policy. In: VALLINDER, T.; TATE, C. Neal. The global expansion of judicial power: the judicialization of politics. New York: NYU Press, 1997). Uma revisão da bibliografia a respeito dessas dimensões, com indicação de estudos nesse sentido no Brasil encontra-se em MACIEL, Débora Alves; KOERNER, Andrei. Sentidos da judicialização da política: duas análises. Lua Nova, n. 57, p. 113-133, 2002.

51 A literatura a respeito da atuação de cortes constitucionais no processo decisório é extensa. Referências importantes sobre o tema podem ser encontradas na discussão de cortes constitucionais como atores de veto feita por Brouard e Hönnige (BROUARD, Silvain; HÖNNIGE, Christoph. Constitutional courts as veto players: lessons from the United States, France and Germany. European Journal of Political Research, v. 56, p. 529-552, 2017). Uma compilação da literatura a esse respeito, com implicações para o estudo de casos no Brasil pode ser encontrada em DA ROS, Luciano. Em que ponto estamos? Agendas de pesquisa sobre o Supremo Tribunal Federal no Brasil e nos Estados Unidos. In: ENGELMAN, Fabiano. Sociologia política das instituiçoes judiciais. Porto Alegre: Editora da UFRGS/CEGOV, 2017. p. 57-97; ARGUELHES, Diego Werneck; RIBEIRO, Leandro Molhano. Contextos da judicialização da política: novos elementos para um mapa teórico. Revista Direito GV, São Paulo, v. 15, n. 2, p. 1-21, 2019.

52 O aspecto "ativista" do comportamento judicial mencionado logo adiante no texto é inclusive uma condição da judicialização da política na elaboração clássica de Tate e Valinder (VALLINDER, T.; TATE, C. Neal. Judicialization and the future of politics and policy. In: VALLINDER, T.; Tate, C. Neal. The global expansion of judicial power: the judicialization of politics. New York: NYU Press, 1997). A possibilidade de atuação legislativa por parte de juízes constitucionais é afirmada também por Stone Sweet (SWEET, Alec Stone. Governing with judges: constitutional politics in Europe. Oxford: Oxford University Press, 2000).

53 KMIEC, Keenan D. The origin and current meanings of judicial activism. California Law Review, v. 92, n. 5, out. 2004.

54 SWEET, Alec Stone. Governing with judges: constitutional politics in Europe. Oxford: Oxford University Press, 2000.

55 Uma discussão a respeito das possibilidades de judicialização da política no Brasil, a partir de fatores explicativos do fenômeno encontrados na literatura sobre o tema pode ser vista em ARGUELHES, Diego Werneck; RIBEIRO, Leandro Molhano. Contextos da judicialização da política: novos elementos para um mapa teórico. Revista Direito GV, São Paulo, v. 15, n. 2, p. 1-21, 2019. 
no Tribunal. ${ }^{56}$ Arantes e Couto mostram, a partir de dados coletados no projeto Comparative Constitutions (2016), que a Constituição brasileira é a terceira maior em uma lista de 190 países. Isso significa que diversos temas podem ter sua constitucionalidade questionada no STF. ${ }^{57}$

Mas, no Brasil, a possibilidade de atuação do STF no processo decisório é ampliada por conta, entre outros fatores, do desenho híbrido do controle de constitucionalidade vigente e as diversas possibilidades de atuação do tribunal por meio de classes processuais que não se referem ao controle de constitucionalidade. Segundo Falcão, Arguelhes e Cerdeira, é possível encontrar três funções distintas exercidas pelo STF: (i) a função típica de um tribunal constitucional em processos de controle concentrado em abstrato de constitucionalidade, que os autores classificam de constitucionais; ${ }^{58}$ (ii) a atuação de controle de constitucionalidade de casos concretos em processo recursais $;^{59}$ e (iii) a atuação em processos ordinários, que, segundo os autores que agrupa as demais possibilidades de atuação do STF. ${ }^{60}$

Relacionado a essas formas de atuação o desenho dos mecanismos de acesso de um tribunal, é importante, entre outros motivos, por definir os atores que podem acessar os tribunais e, assim, tentar vetar mudanças ou promover alterações no status quo ou simplesmente sinalizar suas preferências a demais atores. Conjugado à forma de acesso, o desenho institucional define os recursos processuais pelos quais os diferentes atores (por exemplo, cidadãos em geral, partidos políticos, entidades de classe etc.) podem acionar um tribunal. Ademais, há a definição do quanto e como os tribunais podem influenciar no processo decisório (por exemplo, atuação no controle abstrato ou concreto de constitucionalidade ${ }^{61}$. No Brasil, por exemplo, diversos atores coletivos e individuais podem acionar o STF por meio das mais diferentes classes processuais para interferir no processo político decisório do país, ${ }^{62}$ seja por meio do exercício de funções típicas do controle de constitucionalidade, concentrado ou difuso, seja por meio dos demais processos ordinários, como apresentado acima.

Por fim, as regras internas de decisão de tribunal são importantes porque podem conferir maior ou menor poder a ação individual dos ministros. Como mostram Arguelhes e Ribeiro, ${ }^{63}$ os poderes dos tribunais constitucionais podem ser exercidos de forma coletiva - decisões colegiadas (turmas e/ou plenário, por exemplo) — ou de forma individual, situação na qual um ministro é suficiente para exercer o poder decisório. A ação individual, por sua vez, pode ser classificada como centralizada, ou seja, definida pelo desenho institucional do tribunal — os poderes do presidente ou do relator de um caso, por exemplo — ou como descentralizada, em que qualquer ministro pode exercer o poder, a partir da sua condição de ministro. No Brasil, a conjugação das regras formais e informais do processo decisório interno do STF com as formas de acesso e as diferentes atuações que o tribunal pode exercer ensejam tipos distintos de judicialização da política, mais coletivas ou mais individualizadas. ${ }^{64}$

56 VIEIRA, Oscar Vilhena. Supremocracia. Revista Direito GV, v. 4, n. 2, p. 441-464, 2008.

57 ARANTES, Rogério B.; COUTO, Cláudio G. 1988-2019: trinta anos de constitucionalização permanente. In: SOUZA, André P.; M. FILHO, Naercio. A Carta: para entender a Constituição brasileira. São Paulo: Todavia, 2019. p. 13-52.

58 As classes processuais relacionadas a atuação do STF nesse sentido seriam, segundo os autores, a Ação Declaratória de Constitucionalidade (ADC), Ação Direta de Inconstitucionalidade (ADI), Ação Direta de Inconstitucionalidade por Omissão (ADO), Arguição de Descumprimento de Preceito Fundamental (ADPF), Mandado de Injunção (MI) e Proposta de Súmula Vinculante (PSV).

59 Função que seria exercida por meio dos Agravos de Instrumento (AI) e os Recursos Extraordinários (RE).

60 FALCÃO, Joaquim; CERDEIRA, Pablo de Camargo; ARGUELHES, Diego. I Relatório Supremo em Números: o múltiplo Supremo. Rio de Janeiro: Fundação Getúlio Vargas, 2011.

${ }_{61}$ ARGUELHES, Diego Werneck; RIBEIRO, Leandro Molhano. Contextos da judicialização da política: novos elementos para um mapa teórico. Revista Direito GV, São Paulo, v. 15, n. 2, p. 1-21, 2019.

${ }^{62}$ Normalmente há delimitações de uso de classes processuais por atores. Ou seja, nem todos os recursos de acesso aos tribunais podem ser usados por todos os atores. Para maiores detalhes sobre a relação entre desenho institucional do STF e judicialização da política no Brasil especificamente ver ARGUELHES, Diego Werneck; RIBEIRO, Leandro Molhano. Contextos da judicialização da política: novos elementos para um mapa teórico. Revista Direito GV, São Paulo, v. 15, n. 2, p. 1-21, 2019.

63 ARGUELHES, Diego Werneck; RIBEIRO, Leandro Molhano. 'Ministrocracia'? O Supremo Tribunal Individual e o processo democrático brasileiro. Novos Estudos CEBRAP, v. 37, p. 13-32, 2018.

${ }_{64}$ É possível que atores políticos e individuais acessem o STF e a decisão do tribunal seja coletiva (plenário) ou individual (centrali- 
O MS nº 27.931 é um caso de judicialização da política individualizado nas duas pontas: um parlamentar impetrou um mandado de segurança que foi decidido por meio de uma liminar monocrática do Ministro Celso de Mello. Somente após oito anos do indeferimento da liminar, em 2017, o plenário se pronunciou a respeito, decidindo permanentemente pela denegação. É importante destacar que o controle brasileiro de constitucionalidade segue o modelo repressivo, de modo que a regra seja de que somente leis já promulgadas podem ser anuladas pelo STF. Seguindo essa lógica, apenas leis que fossem promulgadas após terem sido votadas em circunstâncias nas quais a pauta da casa legislativa deveria estar fechada por alguma MP poderiam ser questionadas perante o tribunal por meio de uma Ação Direta de Inconstitucionalidade (ADI). Assim, somente poderia haver uma interpelação judicial após alguma lei promulgada sob a nova interpretação de Michel Temer. Entretanto, o STF possui entendimento que possibilita um controle preventivo do processo legislativo, isto é, antes que a lei seja de fato promulgada com quaisquer vícios formais ou materiais. ${ }^{65}$ Essa interpretação ocorreu em 1980, quando, ao julgar o MS n 20.257 ${ }^{66}$, o ministro Moreira Alves apresentou uma tese ousada que persiste até hoje. Segundo o Ministro, como também há dispositivos constitucionais que regulam o processo legislativo, seria necessário aplicar a Constituição às próprias regras das deliberações legislativas. Desse modo, os parlamentares teriam um direito individual de participar apenas de procedimentos que respeitassem as regras estabelecidas pela Constituição. Abriam-se os caminhos não só para o controle preventivo de leis, mas também para uma judicialização mais individualizada.

Assim, qualquer parlamentar teria (e tem) legitimidade para ajuizar um mandado de segurança individualmente ao STF se considerar que o processo viola alguma norma constitucional e, portanto, seu direito individual como membro de um órgão parlamentar de participar de deliberações somente conforme previsto pela Constituição. O questionamento da constitucionalidade por vício no procedimento legislativo, que - segundo o texto da Constituição de 1988 — só poderia ser feito por meio de uma Ação Direta de Inconstitucionalidade por alguns agentes legitimados. Poderia, a partir de da então, ser questionado por cada parlamentar de forma individual, seguindo os moldes do MS. ${ }^{67}$

A jurisprudência do Tribunal alterou, portanto, de maneira significativa, o desenho institucional no que concerne o acesso ao STF, tendo em vista que possibilitou o controle preventivo e, simultaneamente, aumentou o acesso à Corte por atores individuais por meio de outra classe processual que não a ADI. O acesso à Corte foi expandido e, com isso, o STF também aumentou sua área de atuação, podendo interferir no processo legislativo, como no caso da interpretação de Michel Temer. Do outro lado, a estrutura do processo decisório interno do Tribunal potencializa a descentralização já que permite que um ator individual, no caso o Ministro Celso de Mello, decida sem o a necessidade do aval de uma das turmas ou do plenário. ${ }^{68}$ No dia 27 de março de 2009, apenas nove dias após o MS ter sido impetrado (18 de março de 2009) por Ronaldo Caiado, Celso de Mello indeferiu o pedido de liminar do mandado de segurança. A impetração de um MS pressupõe urgência, sendo a medida cautelar um instrumento importante para essa classe processual de modo a assegurar a celeridade da decisão, mesmo que passível de reversão posteriormente. Cabe, então, ao relator do MS a decisão de conceder ou não a liminar.

Tal poder seria, por si só, neutro, já que estaria sujeito à supervisão do colegiado ${ }^{69}$. Entretanto, o caso evi-

zada ou descentralizada). Ver ARGUELHES, Diego Werneck; RIBEIRO, Leandro Molhano. Contextos da judicialização da política: novos elementos para um mapa teórico. Revista Direito GV, São Paulo, v. 15, n. 2, p. 1-21, 2019.

65 ARGUELHES, Diego Werneck; RIBEIRO, Leandro Molhano. Criatura e/ou criador: transformações do Supremo Tribunal Federal sob a Constituição de 1988. Direito GV, v. 12, n. 2, 2016.

66 BRASIL. Supremo Tribunal Federal. Medida Cautelar do Mandado de Segurança 20.257. Relator: Ministro Celso de Mello. Diário de Justiça, Brasília, DF, 08 out. 2010.

67 Segundo o artigo 103 da Constituição Federal, há apenas nove agentes com legitimidade para propor uma ADI perante o STF. Do Legislativo Federal, apenas a Mesa da Câmara dos Deputados ou um partido político com representação no Congresso Nacional têm tal legitimidade.

68 ARGUELHES, Diego Werneck; RIBEIRO, Leandro Molhano. Contextos da judicialização da política: novos elementos para um mapa teórico. Revista Direito GV, São Paulo, v. 15, n. 2, p. 1-21, 2019.

69 ARGUELHES, Diego Werneck; RIBEIRO, Leandro Molhano. 'The Court, it is I'? Individual judicial powers in the Brazilian 
dencia uma grave disfuncionalidade do Tribunal, tendo em vista que uma decisão individual, que deveria ser temporária torna-se permanente devido à demora do plenário em se manifestar — essa demora cria um alto custo de reversão pelo Plenário. Conforme dito anteriormente, somente em 29 de junho de 2017, oito anos após a decisão liminar, o pleno se manifestou e denegou o MS n 27.931. Assim, verifica-se que os ministros têm um grande poder de alteração ou manutenção do status quo, exercendo tal poder de maneira individual e descentralizada. De fato, a liminar monocrática indeferida por Celso de Mello mostra uma face da judicialização diversa daquela tradicionalmente estudada, quando o STF toma decisões a partir de deliberações colegiadas. A decisão liminar que referendou o entendimento de Michel Temer tem um teor individualizado e descentralizado ${ }^{70}$. Trata-se de uma decisão individualizada porque independe de manifestações do colegiado e descentralizada porque está disponível aos ministros pela simples condição de ser ministro. Diferencia-se de uma decisão centralizada, pois não está vinculada a uma posição institucional fixa, como a do presidente do tribunal — sendo exclusiva a Celso de Mello no caso em questão por ele ser relator do $\mathrm{MS}^{71}$.

Pode-se questionar se a demora de oito anos para a deliberação do Tribunal teria sido intencional, ou seja, se houve demora intencional para Mello colocar o MS na pauta e/ou se foram feitos pedidos de vista com objetivo de esperar um quadro favorável de deliberação. Parece, entretanto, ser mais um caso de demora não intencional: como o indeferimento da liminar já havia servido como uma "confirmação" do entendimento de Temer, desde 2009, a Câmara já não tinha mais sua pauta completamente sobrestada pelo regime de urgência de MPs. O tempo passado entre a liminar, que confirmou a alteração de status quo, e a decisão do STF tornaram o custo de reversão elevado. Ainda que tenha sido o caso de uma demora não intencional, os oito anos que se passaram podem ter funcionado como uma espécie de incentivo para que o MS fosse denegado.

Uma breve linha do tempo do MS no 27.931, após o indeferimento da cautelar por Celso de Mello, parece indicar que a demora não teve objetivos secundários. Oito meses após o indeferimento da liminar, Celso de Mello colocou o MS em pauta, período que não pode ser considerado excessivo. Assim, não parece que Mello teria atrasado o julgamento de modo a obter uma votação favorável. No dia 16 de dezembro de 2009, iniciou-se o julgamento, interrompido por pedido de vista de Carmen Lúcia. A ministra, por sua vez, devolveu os autos para julgamento apenas em 2012, três anos depois. Em 2015, passados mais três anos, reiniciou-se o julgamento, suspenso novamente por pedido de vista de Luís Roberto Barroso, que o devolveu 5 meses depois. A demora do pedido de vista de Carmen Lúcia, embora curiosa, não aparenta ter objetivos de elevar custos de reversão, tendo em vista que ela votou no sentido de denegar o MS, assim como todos os demais, com exceção de Marco Aurélio. No dia 29 de junho de 2017, dois anos depois, o tribunal denegou o MS, confirmando o entendimento de Temer.

Mesmo não havendo uma demora intencional no julgamento, seja pelo relator ou pelos pedidos de vista de Carmen Lúcia e Luís Roberto Barroso, vale ressaltar como a demora de julgamentos após liminar é uma disfuncionalidade do Tribunal. A liminar, que deveria ser um instrumento para resolver temporariamente uma situação de "urgência", acaba por ter o poder de alterar o status quo de forma permanente devido aos altos custos que sua não confirmação pelo Tribunal gera. Como apontado por Arguelhes e Ribeiro ${ }^{72}$, a distinção entre "decisões liminares" e "decisões finais" perde relevância prática quanto aos seus efeitos sobre a política, considerando-se que as liminares se tornam permanentes e os ministros têm um peso institucional equivalente ao de todo um tribunal.

Supreme Court and their implications for constitutional theory. Global Constitutionalism, v. 7, p. 236-262, 2018.

70 ARGUELHES, Diego Werneck; RIBEIRO, Leandro Molhano. 'Ministrocracia'? O Supremo Tribunal Individual e o processo democrático brasileiro. Novos Estudos CEBRAP, v. 37, p. 13-32, 2018.

71 No artigo "Ministrocracia", Arguelhes e Ribeiro chamam atenção ao pedido de vista e à colocação do processo em pauta pelo relator como instrumentos de poder individual descentralizado à disposição dos Ministros. Ver ARGUELHES, Diego Werneck; RIBEIRO, Leandro Molhano. 'Ministrocracia'? O Supremo Tribunal Individual e o processo democrático brasileiro. Novos Estudos CEBRAP, v. 37, p. 13-32, 2018.

72 ARGUELHES, Diego Werneck; RIBEIRO, Leandro Molhano. O Supremo individual: mecanismos de atuação direta dos ministros sobre o processo político. Direito, Estado e Sociedade, n. 46, p. 121-155, 2016. 


\section{Interpretações vinculantes e a autoexpansão dos poderes do STF}

Em seu voto, no julgamento do MS no 27.931, o Ministro Barroso ${ }^{73}$ afirma que deveria haver uma superação da literalidade do texto. Em vez de declarar o $₫ 6^{\circ}$ da EC 32 inconstitucional, o STF deveria adequá-lo à Constituição, tendo em vista existir uma preferência de realizar uma interpretação conforme. A interpretação conforme a Constituição, que foi enunciada pelo Ministro, sendo a tese vencedora no julgamento, é uma técnica hermenêutica segundo a qual, no caso de haver mais de uma interpretação possível de dado dispositivo, deve-se escolher aquela que seja compatível com o ordenamento jurídico. Assim, há uma pressuposição — dos juízes — de que o legislador teria buscado positivar uma norma constitucional, ou seja, há uma presunção de constitucionalidade da lei. ${ }^{74}$

Entretanto, no caso em questão, a interpretação tem uma "dupla face", conforme já apontou Arguelhes em artigo para o Jornal Correio Braziliense, ${ }^{75}$ a decisão não representa somente uma vitória para o então Presidente da Câmara, mas também uma expansão — pela Corte — de seus próprios poderes. Em vez de O STF afirmar que a interpretação é válida por se encontrar dentro da esfera de escolha do Legislativo e, portanto, do Presidente da Câmara, a Corte optou pela tese de que a provisão legislativa só poderia ser considerada constitucional se fosse interpretada exatamente como Temer o fez e foi ratificado pela Corte. Em outras palavras, os ministros decidiram que somente uma interpretação do texto legislativo, aquele anunciado pela Corte, salva o texto de ser declarado inconstitucional, levando em consideração que somente tal interpretação estaria em consonância com a Constituição de 1988. Desse modo, a Corte entende que qualquer decisão relacionada não estaria dentro da margem de escolha do próprio Poder Legislativo, mas sim que tais decisões devem passar pelo crivo da Corte num último momento.

Em seu voto, o ministro Barroso revela — inclusive - certo desconforto na superação da literalidade do dispositivo, que daria lugar à interpretação conforme. Consoante o que foi dito anteriormente, a técnica hermenêutica é usada em casos nos quais há mais de uma interpretação possível de dado dispositivo, presumindo-se pela interpretação que permite a preservação do dispositivo na ordem jurídica. Acontece, no entanto, que o parágrafo $6^{\circ}$ do artigo 62 parece ser bastante claro ao dispor que ficam "sobrestadas [...] todas as demais deliberações legislativas da Casa em que estiver tramitando" (grifos adicionados). Desse modo, a interpretação sugerida por Temer e ratificada pela Casa não parece ser uma interpretação proveniente do texto (dada a palavra "todas" ao se referir às deliberações legislativas), mas sim uma interpretação demasiadamente criativa: um caso de imaginação política formalizado pelo $\mathrm{STF}^{76}$.

É difícil imaginar que o legislador, ao promulgar a EC 32, teria dado ao dispositivo a redação disposta caso pretendesse a interpretação que prevalece atualmente. Parece que o dispositivo foi uma reivindicação da oposição quando da discussão da EC 32 para obrigar o Congresso a deliberar e, ao mesmo tempo, permitir que as minorias tivessem participação no processo legislativo de exame das MPs. Entretanto, é provável que os parlamentares não tenham previsto os contornos da regra, ou seja, que as pautas legislativas se encontrariam recorrentemente trancadas com a continuação da edição excessiva de MPs. Imaginava-se, na verdade, que o trancamento ocorreria somente em situações excepcionais. ${ }^{77}$ Houve, no entanto, deputados que manifestaram preocupação com a regra, já prevendo os efeitos que procederam à promulgação da EC.

\footnotetext{
3 Vídeo "Pleno - Trancamento de pauta da Câmara por MPs não alcança todos os projetos e propostas". Disponível em: https:// www.youtube.com/watch?v=vZ3kMZBvpuE. Acesso em: 03 mar. 2020.

74 MENDES, Gilmar Ferreira; GONET, Paulo Gustavo. Curso de direito constitucional. 13. ed. 2018. p. 1411.

75 ARGUELHES, Diego. A dupla face das decisões do STF. Correio Braziliense, Caderno Opinião, abr. 2009.

76 SHEPSLE, Kenneth A. Rule breaking and political imagination. Chicago: The University Chicago Press, 2017; MUNIZ, Mariana Novotny; RIBEIRO, Leandro Molhano. Imaginação, transgressão e formalização: ações do Congresso e do STF na definição de regras de tramitação de Medidas Provisórias. Revista de Estudos Institucionais, no prelo.

PIRES, Ednilton Andrade. As medidas provisórias e o sobrestamento das demais deliberações legislativas. 2008. Monografia (Especialização) - Curso de Especialização em Processo Legislativo, Centro de Formação, Treinamento e Aperfeiçoamento, Câmara dos Deputados, Brasília, 2008.
} 
Na Reunião da Comissão Especial da PEC, o então ministro do STF Sepúlveda Pertence, por outro lado, afirmou que o dispositivo seria um mecanismo vantajoso tanto para o Congresso, quanto para o Executivo: ${ }^{78}$

vale dizer, o condão de constranger a Maioria parlamentar, de levá-la a deliberar, na medida em que paralisa a atividade do Congresso à vésperas da caducidade da medida provisória, o que é bom, na medida em que dá eficácia ao poder do Congresso; bom, na medida em que dá eficácia à responsabilidade que o Congresso deve assumir, responsabilidade que, na democracia, há de ser sua, em última instância, de deliberar efetivamente a respeito. E, finalmente, bom para o governo, na medida em que força a uma decisão de urgência. Sem isso, repito, abre-se campo a efeito mais perverso dos dois mecanismos, tanto do decreto-lei quanto da prática da medida provisória, que é a da obstrução da Maioria. ${ }^{79}$

Assim, quando começasse o prazo de urgência (após 45 dias da publicação da MP), as demais deliberações legislativas ficariam suspensas até que houvesse a votação da MP. Caso a Emenda de 2001 tivesse alcançado seu objetivo de limitar a edição de MPs pelo Chefe do Poder Executivo, conforme seu objetivo declarado, o regime do prazo de urgência poderia ter funcionado, já que não haveria uma constante e frequente paralisação das atividades legislativas. No entanto, o uso parcimonioso do instrumento normativo, somente "em caso de urgência e relevância", não aconteceu e o parágrafo positivado levou à perda do controle da pauta legislativa pelos parlamentares e à neutralização da regra que possibilitava a perda de eficácia. Se, por um lado, havia a possibilidade — pelo texto constitucional — de os parlamentares não deliberarem sobre MPs sem que isso tivesse custos, levando à perda de eficácia; por outro, na prática, isso teria altos custos para o Congresso, já que suas atividades seriam paralisadas até o fim do regime de urgência (15 dias).

Foi como um tiro no pé dos parlamentares: eles abriram mão de seu poder de agenda, deixando o controle da pauta legislativa à mercê do Presidente da República. Foram salvos, então, pela interpretação de Temer formalizada pelo STF, que possibilitou que o Congresso recuperasse seu poder de agenda e pudesse não deliberar sob MPs de temas politicamente sensíveis ou inoportunos sem que houvesse grandes custos para tal.

\section{Considerações finais}

O caso de judicialização individualizada apresentado acima ilustra aspectos importantes do processo político decisório que pode explicar casos específicos de inovações institucionais em regimes democráticos. Diversos estudos na área de políticas públicas chamam a atenção para a dificuldade de se implementar, em regimes democráticos, medidas cujo propósito é alterar fortemente o status quo — ou seja, a dificuldade de se implementar mudanças inovadoras. ${ }^{80}$ Isso ocorre em grande medida por causa da exigência de formação maiorias requeridas nas arenas decisórias para a implementação de políticas - sejam elas maiorias simples, absoluta ou qualificada. Essa dificuldade está associada à pluralidade de interesses e preferências dos diferentes atores individuais e coletivos que participam do processo decisório. Além disso, regimes democráticos, em geral, distribuem poderes de veto entre atores alocados em diferentes instâncias institucionais justamente para evitar que maiorias sejam tirânicas e infrinjam os direitos de minorias. Uma solução contramajoritária concebida nas democracias constitucionais para frear possíveis ações tirânicas das maiorias é justamente a possibilidade de contestação judicial das decisões majoritárias. O controle de constitucionalidade exercido por tribunais constitucionais assume, assim, um papel de destaque na garantia dos direitos das minorias e,

\footnotetext{
78 PIRES, Ednilton Andrade. As medidas provisórias e o sobrestamento das demais deliberações legislativas. 2008. Monografia (Especialização) - Curso de Especialização em Processo Legislativo, Centro de Formação, Treinamento e Aperfeiçoamento, Câmara dos Deputados, Brasília, 2008.

79 PIRES, Ednilton Andrade. As medidas provisórias e o sobrestamento das demais deliberações legislativas. 2008. Monografia (Especialização) - Curso de Especialização em Processo Legislativo, Centro de Formação, Treinamento e Aperfeiçoamento, Câmara dos Deputados, Brasília, 2008.

80 TSEBELIS, George. Veto players: how political institutions work. Princeton: Princeton University Press, 2002.
} 
não à toa, a judicialização é um fenômeno difundido nas democracias contemporâneas. Isso significa que, além da dificuldade de formação de maiorias para a alteração do status quo, há a possibilidade de atuação contra-majoritária prevista em regimes democráticos, o que pode dificultar ainda mais a alteração do status quo.

Mudanças institucionais dependem da "absorção" dos atores com poderes de veto ao campo de preferências daqueles que pretendem implementá-las. Por isso, mudanças requerem negociações e ajustes mútuos de preferências entre os atores relevantes - normalmente atores coletivos que têm grau de coesão interna variável entre seus membros (partidos políticos, organizações da sociedade civil ou mesmo instâncias colegiadas). Não por acaso, muitos estudos enfatizam o modo incremental das mudanças em políticas públicas nas democracias contemporâneas e a dificuldade de implementação alterações inovadoras. O caso analisado neste artigo ilustra a possibilidade conferida pela judicialização individualizada de promover uma inovação institucional a partir da atuação de poucos atores. Como detalhado anteriormente, o que ocorreu no caso analisado foi que - a partir de uma classe processual específica (mandado de segurança) — um parlamen$\operatorname{tar}$ (acesso individual ao STF) questionou a interpretação dada pelo presidente da Câmara em uma Questão de Ordem a respeito de uma regra que configura um instituto fundamental para o processo político decisório brasileiro (Medida Provisória) e obteve, no curto prazo, uma decisão liminar (decisão judicial individual) que sustentou a alteração do status quo. Tal decisão prevaleceu quando foi julgada pelo Plenário do STF anos mais tarde. Esse é um caso substantivamente relevante pois, por ser uma política que estrutura o próprio processo decisório, a mudança na regra da MP teve consequências importantes para atribuição de poderes de agenda e veto dos principais atores do Executivo e do Legislativo que atuam no nosso presidencialismo de coalizão. ${ }^{81}$

A posição tomada por Temer significou uma inovação institucional importante no instituto da MP e, aparentemente, retirou o poder de obstrução que poderia ser exercido tanto pelo governo, ao editar sucessivas medidas, como pela oposição. Nesse redesenho da tramitação da MP, o STF exerceu um papel relevante ao referendar a decisão de Michel Temer. O contexto da discussão dessa nova interpretação a respeito do sobrestamento leva a crer que Temer estava ciente de que o Supremo interviria e até mesmo parecia querer um posicionamento do tribunal para consolidar institucionalmente a mudança.

\section{Referências}

ABRANCHES, Sérgio. Presidencialismo de coalizão: raízes e evolução do modelo político brasileiro. São Paulo: Companhia das Letras, 2018.

ALMEIDA, Acir. Informação, delegação e processo legislativo: a política das Medidas Provisórias. Texto para discussão - Instituto de Pesquisa Econômica Aplicada. 2014.

ARANTES, Rogério B.; COUTO, Cláudio G. 1988-2019: trinta anos de constitucionalização permanente. In: SOUZA, André P.; M. FILHO, Naercio. A Carta: para entender a Constituição brasileira. São Paulo: Todavia, 2019. p. 13-52.

ARANTES, Rogério. Judiciário: entre a justiça e a política. In: AVELAR, Lúcia; CINTRA, Antonio. Sistema político brasileiro: uma introdução. 2. ed. São Paulo: Konrad Adenauer; Unesp, 2007. p. 81-115.

ARGUELHES, Diego Werneck; RIBEIRO, Leandro Molhano. 'Ministrocracia’? O Supremo Tribunal Individual e o processo democrático brasileiro. Novos Estudos CEBRAP, v. 37, p. 13-32, 2018.

ARGUELHES, Diego Werneck; RIBEIRO, Leandro Molhano. 'The Court, it is I'? Individual judicial powers in the Brazilian Supreme Court and their implications for constitutional theory. Global Constitutionalism,

81 RIBEIRO, Leandro Molhano; MUNIZ, Mariana Novotny. Imaginação, transgressão e formalização: ações do Congresso e do STF na definição de regras de tramitação de Medidas Provisórias. Revista de Estudos Institucionais, no prelo. 
v. 7 , p. $236-262,2018$.

ARGUELHES, Diego Werneck; RIBEIRO, Leandro Molhano. Contextos da judicialização da política: novos elementos para um mapa teórico. Revista Direito GV, São Paulo, v. 15, n. 2, p. 1-21, 2019.

ARGUELHES, Diego Werneck; RIBEIRO, Leandro Molhano. Criatura e/ou criador: transformações do Supremo Tribunal Federal sob a Constituição de 1988. Revista Direito GV, v. 12, n. 2, 2016.

ARGUELHES, Diego Werneck; RIBEIRO, Leandro Molhano. O Supremo Individual: mecanismos de atuação direta dos ministros sobre o processo político. Direito, Estado e Sociedade, n. 46, p. 121-155, 2016.

ARGUELHES, Diego Werneck. Old courts, new beginnings: judicial continuity and constitutional transformation in Argentina and Brazil. 2014. Dissertação (Doutorado) - Faculdade de Direito, Universidade Yale, New Haven, 2014.

ARGUELHES, Diego. A dupla face das decisões do STF. Correio Braziiliense, Caderno Opinião, abr. 2009.

BRASIL. Questão de Ordem 411/2009. Disponível em: https://www2.camara.leg.br/buscaQordem/?wicket:i nterface $=: 10:: .:$. Acesso em: 02 mar. 2020.

BRASIL. Questão de Ordem 536/2005. Disponível em: https://www2.camara.leg.br/buscaQordem/?wicket:i nterface $=: 6:::$. . Acesso em: 02 mar. 2020.

BRASIL. Questão de Ordem 539/2005. Disponível em: https://www2.camara.leg.br/buscaQordem/?wicket:i nterface $=: 8: \cdots:$. Acesso em: 02 mar. 2020.

BRASIL. Questão de Ordem 688/2002. Disponível em: https://www2.camara.leg.br/buscaQordem/?wicket:i nterface=:3:::.:. Acesso em: 02 mar. 2020.

BRASIL. Supremo Tribunal Federal. Ação Direta de Inconstitucionalidade 295. Plenário. Relator: Ministro Marco Aurélio. Sessão de 22/06/1990. Diário de Justiça, Brasília, DF, 22 ago. 1997.

BRASIL. Supremo Tribunal Federal. Medida Cautelar do Mandado de Segurança 27.931. Relator: Ministro Celso de Mello. Diário de Justiça, Brasília, DF, 16 dez. 2015.

BRASIL. Supremo Tribunal Federal. Medida Cautelar do Mandado de Segurança 20.257. Relator: Ministro Celso de Mello. Diário de Justiça, Brasília, DF, 08 out. 2010.

BROUARD, Silvain; HÖNNIGE, Christoph. Constitutional courts as veto players: lessons from the United States, France and Germany. European Journal of Political Research, v. 56, p. 529-552, 2017.

CALIMAN, Auro A. Leis delegadas e medidas provisórias: notas sobre a atividade legislativa do executivo no Brasil. Revista Jurídica "9 de Julho", São Paulo, n. 2, p. 182-203, 2003.

DA ROS, Luciano. Em que ponto estamos? Agendas de pesquisa sobre o Supremo Tribunal Federal no Brasil e nos Estados Unidos. In: ENGELMAN, Fabiano. Sociologia política das instituições judiciais. Porto Alegre: Editora da UFRGS/CEGOV, 2017. p. 57-97.

FALCÃO, Joaquim; CERDEIRA, Pablo de Camargo; ARGUELHES, Diego. I Relatório Supremo em números: o múltiplo Supremo. Rio de Janeiro: Fundação Getúlio Vargas, 2011.

FIGUEIREDO, Argelina; LIMONGI, Fernando. Executivo e Legislativo na nova ordem constitucional. Rio de Janeiro: Editora FGV, 1999.

FIGUEIREDO, Argelina; LIMONGI, Fernando. Instituições políticas e governabilidade: desempenho do governo e apoio legislativo na democracia brasileira. In: MELO, Carlos; SAEZ, Manuel. A democracia brasileira: balanço e perspectivas para o século 21. Belo Horizonte: UFMG, 2007. p. 25-32.

HIRSCHL, Ran. The judicialization of mega-politics and the rise of political courts. Annual Review of Political Science, v. 11, 2008. 
KMIEC, Keenan D. The origin and current meanings of judicial activism. California Law Review, v. 92, n. 5, out. 2004.

LIJPHART, Arend. Modelos de democracia. 3. ed. Rio de Janeiro: Civilização Brasileira, 2003.

LOWI, Theodore J. Four systems of policy, politics, and choice. Public Administration Review, v. 32, n. 4, p. 298-310, 1972.

MACHIAVELI, Fernanda. EC 32: a disputa política em torno da regulamentação das medidas provisórias. $32^{\circ}$ Encontro Anual da Associação Nacional de Pós-Graduação e Pesquisa em Ciências Sociais. GT 21 Estudos Legislativos.

MACHIAVELI, Fernanda. Medidas Provisórias: os efeitos não antecipados da Emenda Constitucional 32 nas relações entre Executivo e Legislativo. 2009. Dissertação (Mestrado) - Faculdade de Filosofia, Letras e Ciências Humanas, Universidade de São Paulo, São Paulo, 2009.

MACIEL, Débora Alves; KOERNER, Andrei. Sentidos da judicialização da política: duas análises. Lua Nova, n. 57, p. 113-133, 2002.

MENDES, Gilmar Ferreira; GONET, Paulo Gustavo. Curso de direito constitucional. 13. ed. 2018. p. 1411.

RIBEIRO, Leandro Molhano; MUNIZ, Mariana Novotny. Imaginação, transgressão e formalização: ações do Congresso e do STF na definição de regras de tramitação de Medidas Provisórias. Revista de Estudos Institucionais, no prelo.

OLIVEIRA, João Paulo de. Medidas Provisórias na Emenda Constitucional 32. Revista Virtual da AGU, Brasília, ano 3, n. 18, 2002.

PAINEL da Folha: Temer consultou Sarney e ministros sobre brecha em MPs. Folha Online, 2009. Disponível em: https://m.folha.uol.com.br/poder/2009/03/536563-painel-da-folha-temer-consultou-sarney-e-ministros-sobre-brecha-em-mps.shtml. Acesso em: 03 mar. 2020.

PIRES, Ednilton Andrade. As medidas provisórias e o sobrestamento das demais deliberacõos legislativas. 2008. Monografia (Especialização) - Curso de Especialização em Processo Legislativo, Centro de Formação, Treinamento e Aperfeiçoamento, Câmara dos Deputados, Brasília, 2008.

SHEPSLE, Kenneth A. Rule breaking and political imagination. Chicago: The University Chicago Press, 2017.

SWEET, Alec Stone. Governing with judges: constitutional politics in Europe. Oxford: Oxford University Press, 2000.

TAYLOR, Matthew. Judging policy: courts and policy reform in democratic Brazil. Stanford: Stanford University Press, 2008.

TAYLOR, Matthew. O judiciário e as políticas públicas no Brasil. Dados, v. 50, n. 2, p. 229-257, 2007.

TSEBELIS, George. Veto players: how political institutions work. Princeton: Princeton University Press, 2002.

VALLINDER, T.; TATE, C. Neal. Judicialization and the future of politics and policy. In: VALLINDER, T.; TATE, C. Neal. The global expansion of judicial power: the judicialization of politics. New York: NYU Press, 1997.

VIEIRA, Oscar Vilhena. Supremocracia. Revista Direito GV, v. 4, n. 2, p. 441-464, 2008. 
Para publicar na revista Brasileira de Políticas Públicas, acesse o endereço eletrônico www.rbpp.uniceub.br

Observe as normas de publicação, para facilitar e agilizar o trabalho de edição. 